\title{
KINERJA KEUANGAN PADA PERUSAHAAN PERTAMBANGAN DI BURSA EFEK INDONESIA
}

\author{
Oleh : \\ Aries Veronica \\ ariesveronica78@gmail.com \\ Fakultas Ekonomi Universitas Tamansiswa \\ Jl. Tamansiswa No. 261 Palembang
}

\begin{abstract}
The purpose of this study was to determine financial performance to stock price of minning industries at Indonesian Stock Exchange. This research is field research with data collection techniques using documentation that the sample size is as much as 33 emitten. To test the effect of the financial performance to stock price used multiple regression analysis techniques and to test research hypotheses, $F$ test and t test.

From the results of calculations using SPSS for Windows version 17, showed that: the value of $R$ Square $\left(R^{2}\right)$ illustrates that the Stock price $(Y)$, can be explained by the financial performance amounted to $65.6 \%$, while the rest $34.4 \%$, can be explained by other factors, which are not included in this study. F Hypothesis test results, obtained value of sig. $(98,701)>(0.05)$, this means that there is influence of the current ratio, total asset turnover, return on investment, and total debt to total asset ratio together against stock price. While the results of hypothesis testing $t$ as follows: 1) sig. (0.000)< (0.05), which means that there is effect current ratio to stock price; 2) sig.(0.004) < (0.05), which means that there is effect debt to equity ratio to stock price; 3) sig.(0.846) > (0.05), which means that there is no effect total asset turnover to stock price; 4) sig.(0.000) (0.05), which means that there is no effect return on investment to stock price, and 5) sig.(0.700)>(0.05), which means that there is no effect total debt to total asset ratio to stock price
\end{abstract}

Keywords: Current Ratio, Debt to Equity Ratio, Total Asset Turnover, Return On Investment, Total debt to total asset ratio, Stock Price

\begin{abstract}
ABSTRAK
Tujuan dari penelitian ini adalah untuk mengetahui kinerja keuangan terhadap harga saham industri pertambangan di Bursa Efek Indonesia. Penelitian ini merupakan penelitian lapangan dengan teknik pengumpulan data dengan menggunakan dokumentasi dengan ukuran sampel sebanyak 33 emiten. Untuk menguji pengaruh kinerja keuangan terhadap harga saham digunakan teknik analisis regresi berganda dan uji hipotesis penelitian, uji F dan uji t. Dari hasil perhitungan menggunakan SPSS untuk Windows versi 17, menunjukkan bahwa: nilai $R$ Square $\left(R^{2}\right)$ menggambarkan bahwa harga saham
\end{abstract}


(Y), dapat dijelaskan oleh kinerja keuangan sebesar 65,6\%, sedangkan sisanya 34,4\% Dapat dijelaskan oleh faktor lain, yang tidak termasuk dalam penelitian ini. Hasil uji Hipotesis F, diperoleh nilai sig. $(98,701)>(0,05)$, hal ini berarti ada pengaruh dari current ratio, Debt to Equity Ratio, total asset turnover, return on investment, dan Total debt to total asset ratio terhadap harga saham. Sedangkan hasil pengujian hipotesis $\mathrm{t}$ sebagai berikut: 1$)$ sig. $(0.000)<(0,05)$, yang berarti ada pengaruh current ratio terhadap harga saham; 2) sig. $(0.004)<(0,05)$, yang berarti ada pengaruh debt to equity ratio terhadap harga saham; 3) sig. $(0.846)>(0,05)$, yang berarti tidak ada pengaruh total asset turnover terhadap harga saham; 4) sig. (0.000) $(0,05)$, yang berarti tidak ada efek return on investment terhadap harga saham, dan 5) sig. $(0.700)>(0,05)$, yang berarti tidak ada pengaruh Total debt to total assets ratio terhadap harga saham

Kata kunci: Current Ratio, Debt to Equity Ratio, Total Asset Turnover, Return On Investment, Total debt to total asset ratio, Harga Saham

\section{PENDAHULUAN}

Laba perusahaan selain merupakan indikator kemampuan perusahaan memenuhi kewajibannya, juga sebagai bahan untuk menunjukan prospek bagi perusahaan lain yang ingin menanamkan modalnya di masa mendatang. Menurut Harahap (2009:263) laba merupakan angka yang penting dalam laporan keuangan karena berbagai alasan antara lain : laba merupakan dasar dalam perhitungan pajak, pedoman dalam menentukan kebijakan investasi dalam pengambilan keputusan, dasar dalam peramalan laba maupun kejadian ekonomi perusahaan lainnya dimasa yang akan datang, dasar dalam perhitungan dan penilaian efisiensi dalam menjalankan perusahaan, serta sebagai dasar dalam penilaian prestasi atau kinerja perusahaan.

Laba yang dihasilkan oleh suatu perusahaan dapat dilihat dari laporan keuangan perusahaan. Laporan keuangan merupakan sumber informasi bagi para investor yang ingin menanamkan modalnya. Semakin banyak keuntungan/ laba yang diperoleh maka akan semakin tinggi harga saham suatu perusahaan. Investor yang teliti akan memilih perusahaan yang memiliki kinerja keuangan yang baik. Mengingat para investor pun sangat mengharapkan keuntungan yang maksimal dengan modal yang mereka tanamkan.

Para investor harus dapat menilai perusahaan mana yang memiliki kemampuan untuk meningkatkan laba dimasa akan datang. Para investor memerlukan data yang 
akurat sebelum memutuskan berinvestasi guna menghindari kerugian karena telah menginvestasikan modal kepada perusahaan yang tidak memiliki kemampuan untuk meningkatkan laba.

Didalam laporan keuangan, selain tercantum laba perusahaan juga terdapat rasio keuangan sebagai tolak ukur untuk membandingkan kinerja keuangan. Rasio keuangan yang baik akan mencerminkan kondisi keuangan yang baik pula, sehingga akan mempengaruhi harga saham. Secara teoritis variasi harga saham akan dipengaruhi oleh kinerja keuangan perusahaan disamping dipengaruhi oleh hukum permintaan dan penawaran.

Jika kinerja keuangan perusahaan mengalami peningkatan, maka harga saham akan merefleksikannya dengan peningkatan harga saham demikian juga sebaliknya.Salah satu cara untuk menilai kinerja perusahaan adalah dengan cara mengukur kinerja keuangan perusahaan yang diperlukan untuk menentukan untuk keberhasilan dalam mencapai keberhasilan tersebut. Kinerja keuangan sendiridapat dilakukan dengan menggunakan rasio laporan keuangan yang mendasar pada pendekatan earnings measures.

Informasi tentang kinerja perusahaan merupakan salah satu informasi yang penting dan salah satu jenis informasi yang menjadi pertimbangan investor dalam mengambil keputusan investasinya. Kinerja perusahaan pada umumnya dinilai dari perbandingan rasio unsur- unsur fundamental dalam perusahaan tersebut.Investasi dalam bentuk saham memiliki resiko yang sangat besar. Harga saham merupakan harapan investor. Kinerja perusahaan akan menentukan tinggi rendahnya harga saham di pasar modal. Investor diharapkan sebelum menanamkan dananya sebaiknya melihat kinerja perusahaan dari laporan keuangan yang diterbitkan secara periodik.

Kesalahan dalam pemilihan saham yang akan dibeli dapat mengakibatkan kerugian yang fatal. Oleh karena itu investor harus dapat memilih dengan baik saham yang akan dibelinya. Pemilihan ini dapat dilakukan dengan melihat kinerja perusahaan dalam kurun waktu tertentu.

Harga saham sangat berpengaruh untuk menunjang persaingan antar perusahaan di pasar modal.Pasar modal memang sangat diperlukan keberadaannya dalam suatu 
negara, karena pasar modal menjalani fungsi ekonomi dan keuangan (Husnan, 2007 : 4). Pasar modal merupakan sarana untuk mempertemukan perusahaan yang membutuhkan dana dan perusahaan yang ingin menanamkan modalnya.

Dalam melakukan prediksi harga saham terdapat pendekatan dasar yaitu analisis fundamental dan analisis teknikal. Analisis ini digunakan untuk mengetahui kinerja keuangan perusahaan dengan menggunakan rasio- rasio. Salah satu rasio yang digunakan adalah rasio profitabilitas, karena rasio ini bisa dijadikan informasi laba bagi para investor untuk mengetahui kondisi perusahaan tersebut.

Setelah penjabaran diatas, dapat diketahui bahwa kinerja keuangan suatu perusahaan sangat berpengaruh terhadap harga saham di Bursa Efek Indonesia (BEI). Penelitian ini bertujuan untuk mengetahui Pengaruh kinerja keuangan terhadap harga saham pada perusahaan pertambangan di Bursa Efek Indonesia (BEI).

\section{TINJAUAN PUSTAKA}

\section{Kinerja Keuangan}

Kinerja perusahaan adalah suatu usaha formal yang dilaksanakan perusahaan untuk mengevaluasi efisien dan efektivitas dari aktvitas perusahaan yang telah dilaksanakan pada periode waktu tertentu. Pengukuran kinerja keuangan merupakan analisis data serta pengendalian bagi perusahaan. Pengukuran kinerja digunakan perusahaan untuk melakukan perbaikan diatas kegiatan operasionalnya agar dapat bersaing dengan perusahaan lain. Bagi investor informasi mengenai kinerja perusahaan dapat digunakan untuk melihat apakah mereka akan mempertahankan investasi mereka diperusahaan tersebut atau mencari alternatif lain. Selain itu pengukuran juga dilakukan untuk memperlihatkan kepada penanam modal maupun pelanggan atau masyarakat secara umum bahwa perusahaan memiliki kredibilitas yang baik (Munawir, 2002 : 53)

Menurut Sucipto (2003 : 6) pengertian kinerja keuangan adalah penentuan ukuran-ukuran tertentu yang dapat mengukur keberhasilan suatu organisasi atau perusahaan dalam menghasilkan laba. Sedangkan menurut IAI (2015) kinerja keuangan adalah kemampuan perusahaan dalam mengelola dan mengendalikan sumber daya yang dimilikinya. Sedangkan menurut Fahmi (2011:2) kinerja keuangan adalah suatu analisis 
yang dilakukan untuk melihat sejauh mana suatu perusahaan telah melaksanakan dengan menggunakan aturan - aturan pelaksanaan keuangan dengan baik dan benar. Kinerja perusahaan merupakan suatu gambaran tentang kondisi keuangan suatu perusahaan yang dianalisis dengan alat- alat analisis keuangan, sehingga dapat diketahui mengenai baik buruknya keadaan keuangan suatu perusahaan yang mencerminkan prestasi kerja dalam suatu periode tertentu.

Berdasarkan pengertian diatas, diambil kesimpulan bahwa kinerja keuangan merupakan kemampuan perusahaan dalam mengelola kondisi keuangan dan mengendalikan sumber daya yang dimiliki agar dapat mencerminkan naik turunnya prestasi perusahaan.

\section{Faktor - Faktor yang Mempengaruhi Kinerja Perusahaan.}

Menurut Agnes (2009) faktor- faktor yang mempengaruhi kinerja perusahaan adalah sebagai berikut :

1. Faktor internal

a. Manajemen personalia

Berkaitan dengan sumber daya manusia agar dapat didayagunakan seoptimal mungkin untuk mencapai tujuan perusahaan secara manusiawi

b. Managemen pemasaran

Berkaitan dengan program- program yang ditujukan untuk mencapai tujuan perusahaan.

c. Managemen produksi

Berkaitan dengan faktor- faktor produksi agar barang dan jasa sesuai dengan yang diharapkan.

d. Managemen keuangan

Berkaitan dengan perencanaan, mencari, dan memanfaatkan dan untuk memaksimum efisiensi perusahaan.

\section{Faktor Eksternal}

a. Kondisi perekonomian

Kondisi yang dipengaruhi kebijakan pemerintah, keadaan dan stabilitas politik, ekonomi, social, dan lain- lain.

b. Kondisi industry

Meliputi tingkat persaingan, jumlah perusahaan, dan lain- lain. 


\section{Rasio Keuangan}

Pengukuran kinerja perusahaan dengan menggunakan ukuran rasio sudah menjadi suatu parameter yang terbilang umum saat ini. Menurut Munawir (2002) Rasio Keuangan merupakan suatu metode analisis untuk mengetahui hubungan dari pos- pos tertentu dalam neraca atau laporan laba rugi secara individu atau kombinasi dari kedua laporan tersebut. Sedangkan menurut Harahap (2009) rasio keuangan adalah angka yang diperoleh dari hasil perbandingan dari suatu pos laporan keuangan dengan pos lainnya yang mempunyai hubungan yang relevan dan signifikan.

\section{Manfaat Rasio Keuangan}

Manfaat rasio keuangan menurut Agnes (2009) adalah : 1) Mengidentifikasi kelemahan dan kekuatan perusahaan dibidang keuangan; 2) Mengetahui kinerja perusahaan; 3) Membantu dalam pengawasan perusahaan; 4) Membantu pimpinan perusahaan dalam pengambilan keputusan; dan 5) Melihat perkembangan perusahaan selama beberapa waktu.

\section{Jenis- Jenis Ratio Keuangan}

Agnes (2009) mengatakan rasio dapat diklasifikasikan sebagai berikut :

1. Rasio Likuiditas, yaitu rasio yang menunjukan kemampuan perusahaan untuk memenuhi kewajiban financial yang berjangka pendek tepat pada waktunya. Contohnya : Current Ratio.

2. Rasio financial leverage, yaitu rasio yang menunjukan kapasitas perusahaan untuk memenuhi kewajiban baik jangka pendek maupun jangka panjang. Contohnya : Debt to equity ratio, dan total debt to total asset ratio.

3. Rasio aktivitas, yaitu rasio yang menunjukan sejauh mana efisiensi perusahaan dalam menggunakan aset- asetnya untuk memperoleh penghasilan dari kegiatan penjualan. Contohnya : total asset turnover.

4. Rasio profitabilitas, yaitu rasio yang digunakan untuk mengukur seberapa besar kemampuan perusahaan memperoleh laba baik dalam hubungannya dengan penjualan, asset, maupun laba bagi modal sendiri. Contohnya : return on investmen.

\section{Pasar Modal}

Menurut Sunariyah (2006:5) Pasar modal adalah tempat pertemuan antara penawaran dengan permintaan surat berharga. Sedangkan menurut Fahmi (2011: 34) pasar modal merupakan tempat dana - dana modal seperti ekuitas dan utang 
diperdagangkan. Menurut Husnan (2007:3) Pasar modal dapat didefiisikan sebagai pasar untuk berbagai instrumen keuangan (sekuritas) jangka panjang yang dapat diperjualbelikan, baik dalam bentuk hutang maupun modal sendiri. Baik itu diterbitkan oleh Pemerintah, public authoritis, maupun perusahaan swasta.

Pengertian diatas dapat ditarik kesimpulan bahwa pasar modal adalah suatu tempat bertemunya penjual dan pembeli untuk berbagai instrument keuangan jangka panjang yang bias diperjual belikan baik dalam bentuk hutang maupun dalam bentuk modal.

\section{Peranan Pasar Modal}

Seberapa besar peranan pasar modal menurut Sunariyah (2006:7) dapat dilihat dari 5 (lima) segi, sebagai berikut :

1. Sebagai fasilitas melakukan interaksi antara pembeli dengan penjual untuk menentukan harga saham atau surat berharga yang diperjualbelikan.

2. Memberikan kesempatan kepada para pemodal untuk menentukan hasil (return) yang diharapkan.

3. Memberikan kesempatan kepada para investor untuk menjual kembali saham yang dimilikinya atau surat berharga lainnya.

4. Menciptakan kesempatan kepada masyarakat untuk berpartisipasi dalam perkembangan suatu perekonomian.

5. Mengurangi biaya informasi dan transaksi surat berharga.

\section{Pengertian Harga Saham}

Pengertian Harga Saham menurut Martono dan Harjito (2010:13) didefinisikan sebagai refleksi dari keputusan-keputusan investasi, pendanaan (termasuk kebijakan dividen) dan pengelolaan aset. Sedangkan menurut Widoatmodjo (2005:102) mendefinisikan harga saham adalah harga jual dari investor yang satu kepada investor yang lain setelah saham tersebut di cantumkan di bursa, baik bursa utama maupun OTC (Over the counter market)".

\section{Penilaian Harga Saham.}

Menurut Sunariyah (2006:168-179) ada beberapa pendekatan yang dapat digunakan untuk menilai harga suatu saham tetapi dua pendekatan berikut yang paling banyak digunakan, yaitu pendekatan tradisional dan pendekatan portofolio modern. 
1. Pendekatan tradisional, untuk menganalisis surat berharga saham denganpendekatan tradisional digunakan dua analisis yaitu:

a. Analisis teknikal, merupakan suatu teknik analisis yang menggunakandata atau catatan mengenai pasar itu sendiri untuk berusaha mengaksespermintaan dan penawaran suatu saham tertentu maupun pasar secarakeseluruhan. Pendekatan analisis ini menggunakan data pasar yangdipublikasikan seperti: harga saham, volume perdagangan, indeksharga saham gabungan dan individu, serta faktor faktor lain yangbersifat teknis. Oleh sebab itu, pendekatan ini juga disebut pendekatananalisis pasar (market analisys) atau analisis internal (internalanalisys).

b. Analisis fundamental, pendekatan ini didasarkan pada suatu anggapanbahwa setiap saham memiliki nilai intrinsik. Nilai intrinsik inilah yangdiestimasi oleh para investor atau analisis. Nilai intrinsik merupakansuatu fungsi dari variabelvariabel perusahaan yang dikombinasikanuntuk menghasilkan suatu return (keuntungan) yang diharapkan dansuatu resiko yang melekat pada saham tersebut. Hasil estimasi nilaiintrinsik kemudian dibandingkan dengan harga pasar yang sekarang(current market price). Harga pasar saham merupakan refleksi dariratarata nilai intrinsiknya

\section{Pendekatan portofolio modern}

Pendekatan portofolio modern menekankan pada aspek psikologi bursadengan asumsi hipotesis mengenai bursa, yaitu hipotesis pasar efisien.Pasar efisien diartikan bahwa harga-harga saham yang terefleksikan secaramenyeluruh pada seluruh informasi yang ada di bursa.

\section{Kerangka Pemikiran}

\section{Gambar 1}

Kerangka Pemikiran

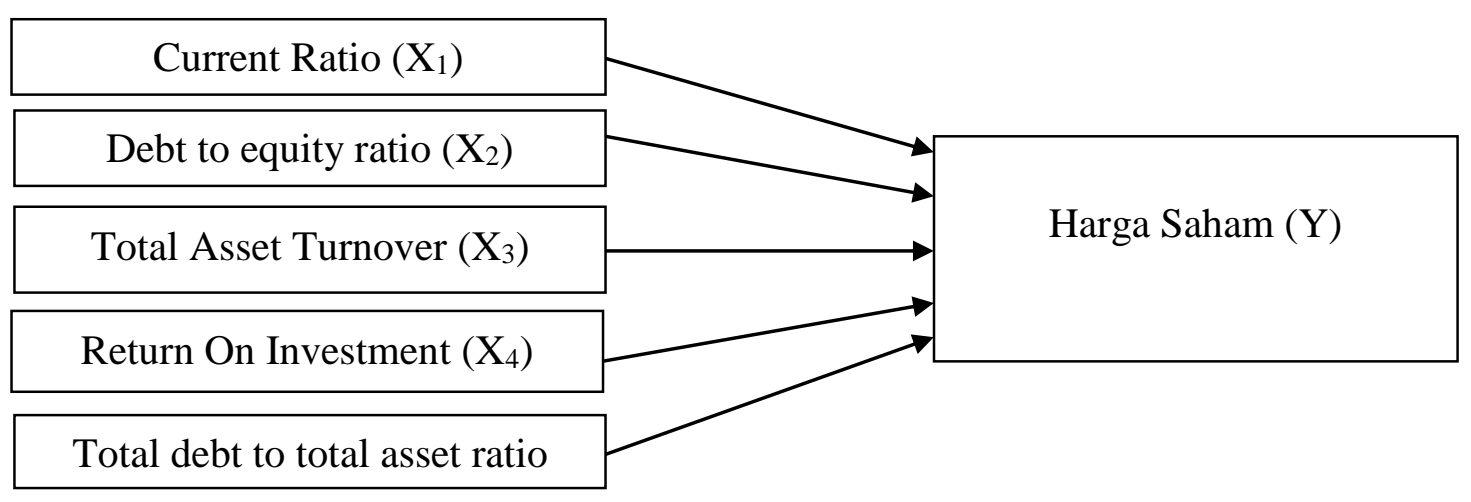

Perubahan harga saham di pasar modal dipengaruhi oleh berbagai faktor. Berdasarkan beberapa penelitian terdahulu disebutkan bahwa informasi tentang kinerja perusahaan merupakan salah satu faktor yang mempunyai pengaruh terhadap perubahan 
harga saham. Pada penelitian ini, peneliti menggunakan empat rasio keuangan yaitu current ratio, debt to equity ratio, total asset turnover, return on investmen, dan total debt to assets ratio.

\section{Hipotesis}

$\mathrm{H}_{1}$ : ada pengaruh signifikan current ratio, debt to equity ratio, total asset turnover, return on investment, dan debt to total asset ratio terhadap harga saham pada perusahan pertambangan di Bursa Efek Indonesia.

$\mathrm{H}_{2}$ : ada pengaruh signifikan current ratio terhadap harga saham perusahan pertambangan

di Bursa Efek Indonesia.

$\mathrm{H}_{3}$ : ada pengaruh signifikan debt to equity ratio terhadap harga saham perusahaan pertambangan di Bursa Efek Indonesia

$\mathrm{H}_{4}$ : ada pengaruh signifikan total assets turnover terhadap harga saham perusahaan pertambangan di Bursa Efek Indonesia.

$\mathrm{H}_{5}$ : ada pengaruh signifikan return on investment terhadap harga saham perusahaan pertambangan di Bursa Efek Indonesia.

$\mathrm{H}_{6}$ : ada pengaruh signifikan total debt to total asset ratioterhadap harga saham perusahaan

pertambangan di Bursa Efek Indonesia.

\section{METODE PENELITIAN}

Penelitian ini dilakukan pada data perusahaan pertambangan yang terdapat di Bursa Efek Indonesia. Ruang lingkup pada penelitian ini adalah terbatas pada pengaruh Current Ratio, Debt to Equity Ratio, Operating Profit Margin, Price Earning Ratio, Return on Investment, Total Assets Turnover, Total Debt to Total Assets Ratio terhadap harga saham perusahaan pertambanga yang terdaftar di Bursa Efek Indonesia tahun 2012 $-2015$.

Penelitian ini menggunakan data sekunder yang umumnya bukti, catatan atau laporan historis yang telah tersusun di dalam arsip (data dokumenter) dipublikasikan. Populasi dalam penelitian ini adalah seluruh perusahaan pertambangan yang terdaftar di Bursa Efek Indonesia (BEI) periode tahun 2012-2015. Pemilihan sampel dalam penelitian ini menggunakan teknik purposive sampling, dengan kriteria-kriteria yang digunakan sebagai berikut: 1) Perusahaan pertambangan yang terdaftar di Bursa Efek Indonesia berturut-turut tahun 2012-2015; 2) Menerbitkan laporan keuangan untuk 
periode 2012 - 2015; 3) Memiliki data lengkap yang diperlukan dalam penelitian ini. Setelah dilakukan pengambilan sampling berdasarkan kriteria- kriteria diatas, maka pada akhirnya terpilih 33 sampel perusahaan (pada lampiran 2), yaitu :

Tabel 1

Proses Pemilihan Sample Penelitian

\begin{tabular}{|c|l|c|}
\hline No & \multicolumn{1}{|c|}{ Keterangan } & Jumlah \\
\hline 1 & $\begin{array}{l}\text { Perusahaan pertambangan yang terdaftar di Bursa Efek } \\
\text { Indonesia 2012-2015 }\end{array}$ & 39 \\
\hline 2 & Data Laporan Keuangan tidak lengkap periode 2012-2015 & 6 \\
\hline \multicolumn{1}{|c|}{ Total Sampel } & 33 \\
\hline
\end{tabular}

(Sumber : data yang diolah, 2017)

Teknik analisis yang digunakan meliputi : (1) statistik deskriptif; (2) uji asumsi klasik; dan (3) uji statistik. Untuk mendukung analisis data digunakan bantuan software SPSS for windows vesi 17. Secara umum model regresi linier berganda untuk populasi adalah sebagai berikut:

$$
\mathrm{Y}=\beta 0+\beta 1 \mathrm{X}_{1}+\beta 2 \mathrm{X}_{2+} \beta 3 \mathrm{X}_{3}+\beta 4 \mathrm{X}_{4+} \beta 5 \mathrm{X}_{5+\varepsilon}
$$

Keterangan :

$\begin{array}{lll}\beta 0 & = & \text { Konstanta } \\ \beta 1 \beta 2 \beta 3 & = & \text { Koefisien regresi untuk variabel independen } \\ \mathrm{Y} & = & \text { Variabel dependen } \\ \mathrm{X}_{1} & = & \text { Variabel independen1 (Current Ratio) } \\ \mathrm{X}_{2} & = & \text { Variabel independen2 (Debt To Equity Ratio) } \\ \mathrm{X}_{3} & = & \text { Variabel independen3 (Operating Profit Margin) } \\ \mathrm{X}_{4} & = & \text { Variabel independen4(Price Earning Ratio) } \\ \mathrm{X}_{5} & = & \text { Variabel independen5(Total Assets Turn Over) }\end{array}$




\section{ANALISIS DAN PEMBAHASAN}

\section{Pengujian Asumsi Klasik}

\section{Uji Normalitas}

Tabel 2

Hasil Pengujian Normalitas

One-Sample Kolmogorov-Smirnov Test

\begin{tabular}{|ll|r|}
\hline & & $\begin{array}{c}\text { Unstandardized } \\
\text { Residual }\end{array}$ \\
\hline Normal Parameters ${ }^{\mathrm{a}, \mathrm{b}}$ & Mean & 131 \\
& Std. Deviation & .0000000 \\
Most Extreme Differences & Absolute & .10409105 \\
& Positive & .062 \\
& Negative & .062 \\
Kolmogorov-Smirnov Z & & -.039 \\
Asymp. Sig. (2-tailed) & & .707 \\
\end{tabular}

a. Test distribution is Normal.

b. Calculated from data.

Sumber : hasil pengujian SPSS 17.0, 2017

Berdasarkan tabel 2 diatas menunjukan bahwa nilai signifikasi sebesar 0.700 dimana signifikasi two tailed lebih besar dari 0,05. Hal ini membuktikan bahwa data telah terdistribusi secara normal.

\section{Uji Multikolinearitas}

Tabel 3

Hasil Pengujian Multikolinearitas

Coefficients $^{a}$

\begin{tabular}{|c|c|c|c|c|c|c|c|c|}
\hline \multirow{2}{*}{\multicolumn{2}{|c|}{ Model }} & \multicolumn{2}{|c|}{$\begin{array}{l}\text { Unstandardized } \\
\text { Coefficients }\end{array}$} & \multirow{2}{*}{$\begin{array}{c}\begin{array}{c}\text { Standardized } \\
\text { Coefficients }\end{array} \\
\text { Beta }\end{array}$} & \multirow[b]{2}{*}{$t$} & \multirow[b]{2}{*}{ Sig. } & \multicolumn{2}{|c|}{ Collinearity Statistics } \\
\hline & & B & Std. Error & & & & Tolerance & VIF \\
\hline \multirow[t]{6}{*}{1} & (Constant) & .155 & .026 & & 5.886 & .000 & & \\
\hline & CRT1 & .128 & .006 & .831 & 20.668 & .000 & .999 & 1.001 \\
\hline & DERT1 & -.036 & .013 & -.240 & -2.906 & .004 & .237 & 4.227 \\
\hline & TATT1 & .002 & .011 & .011 & .194 & .846 & .545 & 1.834 \\
\hline & ROIT1 & .046 & .008 & .275 & 5.582 & .000 & .665 & 1.505 \\
\hline & DART1 & .008 & .022 & .035 & .386 & .700 & .199 & 5.021 \\
\hline
\end{tabular}

a. Dependent Variable: Unstandardized Residual

Sumber : hasil pengujian SPSS 17.0, 2017

Melihat dari hasil besaran korelasi antar variabel independen tampak bahwa hanya nilai tolerance semua variabel independen lebih besar dari 0,10. Nilai VIF semua 
variabel independen lebih kecil dari 10,00. Dari kesimpulan diatas maka dapat dikatakan tidak terjadi multikolinearitas yang serius.

\section{Uji Heterokedastisitas}

Hasil pengujian Heterokedastisitas adalah sebagai berikut :

\section{Tabel 4}

Hasil Pengujian Heterokedastisitas

Coefficients $^{\mathrm{a}}$

\begin{tabular}{|c|c|c|c|c|c|c|}
\hline \multirow{2}{*}{\multicolumn{2}{|c|}{ Model }} & \multicolumn{2}{|c|}{ Unstandardized Coefficients } & \multirow{2}{*}{$\begin{array}{c}\begin{array}{c}\text { Standardized } \\
\text { Coefficients }\end{array} \\
\text { Beta }\end{array}$} & \multirow[b]{2}{*}{$\mathrm{t}$} & \multirow[b]{2}{*}{ Sig. } \\
\hline & & $\mathrm{B}$ & Std. Error & & & \\
\hline \multirow[t]{6}{*}{1} & (Constant) & .081 & .016 & & 4.993 & .000 \\
\hline & CRT1 & -.007 & .004 & -.169 & -1.926 & .056 \\
\hline & DERT1 & .001 & .008 & .024 & .131 & .896 \\
\hline & TATT1 & -.004 & .007 & -.062 & -.524 & .602 \\
\hline & ROIT1 & .003 & .005 & .065 & .601 & .549 \\
\hline & DART1 & -.006 & .014 & -.081 & -.410 & .683 \\
\hline
\end{tabular}

a. Dependent Variable: Abs_res

Sumber : hasil pengujian SPSS 17.0, 2017

Pada tabel 4 menunjukan bahwa tidak ada gangguan heterokedastisitas yang terjadi dalam pengaruh kinerja keuangan terhadap harga saham pada perusahaan pertambangan di bursa efek indonesia, dimana tidak ada nilai hitung yang signifikan atau nilai signifikan (sig) lebih dari 0,05 ( $\mathrm{p}>0,05$ ). Jadi secara keseluruhan dapat disimpulkan bahwa tidak ada masalah heterokedastisitas.

\section{Uji Autokorelasi}

Tabel 5

Hasil Pengujian Autokorelasi Model Summaryb

\begin{tabular}{|l|r|r|r|r|r|}
\hline Model & $\mathrm{R}$ & $\mathrm{R}$ Square & \multicolumn{1}{|c|}{$\begin{array}{c}\text { Adjusted R } \\
\text { Square }\end{array}$} & $\begin{array}{c}\text { Std. Error of the } \\
\text { Estimate }\end{array}$ & Durbin-Watson \\
\hline 1 & $.893^{\mathrm{a}}$ & .798 & .790 & .10615246 & 1.856 \\
\hline
\end{tabular}

a. Predictors: (Constant), DART1, CRT1, ROIT1, TATT1, DERT1

b. Dependent Variable: Unstandardized Residual

Sumber : hasil pengujian SPSS 17.0, 2017 
Berdasarkan tabel 5 nilai Durbin Watson (DW) dalam analisis diperoleh sebesar 1,856. Nilai ini kita bandingkan dengan nilai tabel dengan menggunakan signifikasi 5\% jumlah sampel 131 (n) dan jumlah variabel independen $(k=5)$. Nilai DW lebih besar dari batas atas (du) 1,77945 dan kurang dari 4 - 1,77945. Maka dapat disimpulkan bahwa tidak ada autokorelasi positif atau negatif atau dapat disimpulkan tidak terjadi autokorelasi.

\section{Pengujian Hipotesis Uji Pengaruh Simultan (Uji F)}

Uji pengaruh simultan digunakan untuk mengetahui apakah variabel independen secara bersama- sama atau simultan mempengaruhi variabel dependen.

\section{Tabel 6}

\section{Hasil Pengujian Hipotesis}

ANOVA $^{\text {b }}$

\begin{tabular}{|ll|r|r|r|r|r|}
\hline Model & & Sum of Squares & df & Mean Square & F & Sig. \\
\hline 1 & Regression & 5.561 & 5 & 1.112 & 98.701 & $.000^{\mathrm{a}}$ \\
& Residual & 1.409 & 125 & .011 & & \\
& Total & 6.970 & 130 & & & \\
\end{tabular}

a. Predictors: (Constant), DART1, CRT1, ROIT1, TATT1, DERT1

b. Dependent Variable: Unstandardized Residual

Sumber : hasil pengujian SPSS 17.0, 2017

Pada tabel 6 didapat sig. F sebesar 98,701 lebih besar dari signifikan sebesar 0,05. Ini menunjukan bahwa current ratio, debt to equity ratio, total asset turnover, Return On Investment dan total debt to total asset ratio secara simultan tidak berpengaruh terhadap harga saham pertambangan yang terdaftar di Bursa Efek Indonesia. 
Pengujian Parsial (Uji t)

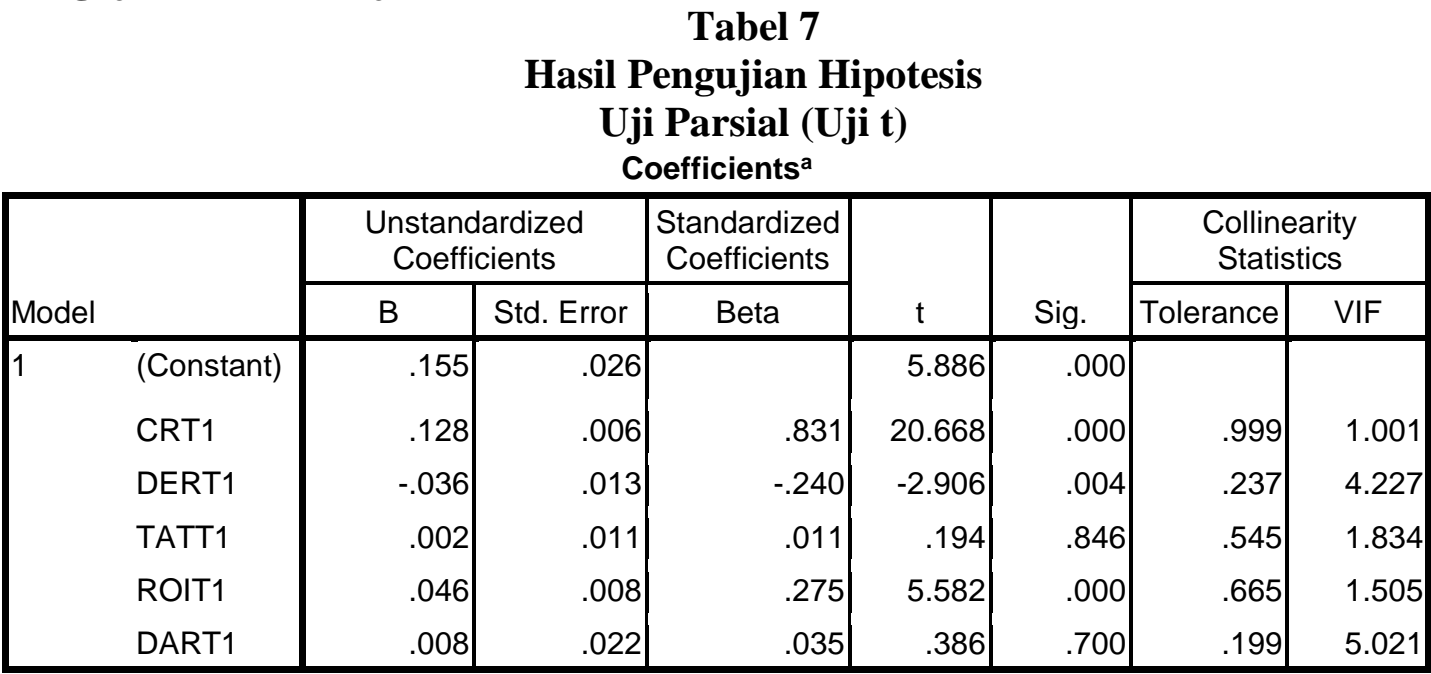

a. Dependent Variable: Unstandardized Residual

Sumber : hasil pengujian SPSS 17.0, 2017

Berdasarkan output coefisien diatas, diketahui bahwa hanya nilai koefisien variabel current ratio dan variabel return on investment yang bernilai positif terhadap variabel Y sehingga dapat dikatakan bahwa variabel current ratio dan variabel return on investment berpengaruh positif terhadap variabel harga saham. Pengaruh positif diartikan bahwa semakin meningkat volume total asset turnover dan variabel return on investment (X) maka semakin meningkat pula harga saham (Y)

\section{Pengaruh Current Ratio terhadap Harga Saham pada Perusahaan Pertambangan di}

\section{Bursa Efek Indonesia.}

Hasil pengujian untuk variabel current ratio menunjukan nilai signifikan sebesar 0,00 dimana lebih kecil dari 0,05. Karena nilai signifikan lebih kecil daripada 0,05 maka hal ini membuktikan bahwa current ratio berpengaruh terhadap harga saham. Hasil penelitian ini sebanding dengan penelitian Kurniawan (2008) yang menyatakan bahwa secara serentak semua rasio keuangan berpengaruh terhadap perubahan saham. Hasil penelitian ini pula sebanding dengan hasil penelitian yang dilakukan oleh Megarini (2003) yang menemukan current ratio mempunyai pengaruh terhadap perubahan harga saham pada perusahaan di bursa efek Indonesia. 


\section{Pengaruh Debt to Equity Ratio terhadap Harga Saham pada Perusahaan} Pertambangan di Bursa Efek Indonesia.

Hasil pengujian untuk variabel debt to equity ratio menunjukan nilai signifikan sebesar 0,004 dimana lebih kecil dari 0,05. Karena nilai signifikan lebih kecil daripada 0,05 maka hal ini membuktikan bahwa debt to equity ratio berpengaruh terhadap harga saham. Hasil penelitian ini sebanding dengan penelitian Kurniawan (2008) yang menyatakan bahwa secara serentak semua rasio keuangan berpengaruh terhadap perubahan saham. Namun hasil penelitian ini tidak sebanding dengan hasil penelitian yang dilakukan oleh Megarini (2003) yang menemukan bahwa variabel debt to equity ratio tidak berpengaruh terhadap perubahan harga saham pada perusahaan di bursa efek Indonesia.

Pengaruh Total Asset Turnover terhadap Harga Saham pada Perusahaan Pertambangan di Bursa Efek Indonesia.

Hasil pengujian untuk variabel total asset turnover menunjukan nilai signifikan sebesar 0,846 dimana lebih besar dari 0,05. Karena nilai signifikan lebih besar daripada 0,05 maka hal ini membuktikan bahwa total asset turnover tidak berpengaruh terhadap harga saham. Hasil penelitian ini tidak sebanding dengan penelitian Kurniawan (2008) yang menyatakan bahwa secara serentak semua rasio keuangan berpengaruh terhadap perubahan saham. Hasil penelitian ini pula sebanding dengan hasil penelitian yang dilakukan oleh Megarini (2003) yang menemukan bahwa variabel total asset turnover tidak berpengaruh terhadap perubahan harga saham pada perusahaan di bursa efek Indonesia.

\section{Pengaruh Return on Investment terhadap Harga Saham pada Perusahaan Pertambangan di Bursa Efek Indonesia.}

Hasil pengujian untuk variabel return on investment menunjukan nilai signifikan sebesar 0,000 dimana lebih kecil dari 0,05. Karena nilai signifikan lebih kecil daripada 0,05 maka hal ini membuktikan bahwa total asset turnover berpengaruh terhadap harga saham. Hasil penelitian ini sebanding dengan penelitian Kurniawan (2008) yang 
menyatakan bahwa secara serentak semua rasio keuangan berpengaruh terhadap perubahan saham. Namum hasil penelitian ini tidak sebanding dengan hasil penelitian yang dilakukan oleh Megarini (2003) yang menemukan bahwa variabel return on investment tidak berpengaruh terhadap perubahan harga saham pada perusahaan di bursa efek Indonesia.

\section{Pengaruh Total Debt to Total Asset Ratio terhadap Harga Saham pada Perusahaan Pertambangan di Bursa Efek Indonesia.}

Hasil pengujian untuk variabel total debt to total asset ratio menunjukan nilai signifikan sebesar 0,700 dimana lebih besar dari 0,05. Karena nilai signifikan lebih besar daripada 0,05 maka hal ini membuktikan bahwa total asset turnover tidak berpengaruh terhadap harga saham. Hasil penelitian ini tidak sebanding dengan penelitian Kurniawan (2008) yang menyatakan bahwa secara serentak semua rasio keuangan berpengaruh terhadap perubahan saham. Namum hasil penelitian ini sebanding dengan hasil penelitian yang dilakukan oleh Megarini (2003) yang menemukan bahwa variabel total debt to total asset ratio berpengaruh terhadap perubahan harga saham pada perusahaan di bursa efek Indonesia.

Variabel kinerja perusahaan dinilai dengan total aset yang dimiliki perusahaan, semakin besar total aset yang dimiliki perusahaan maka perusahaan tersebut memiliki sumber daya yang baik pula serta lebih banyak informasi yang diungkapkan. Selain itu, perusahaan besar menjadi entitas yang banyak disorot pasar maupun publik karena mereka yang lebih banyak mengungkapkan informasi sebagai bentuk akunbilitasnya. Sehingga dapat disimpulkan semakin besar ukuran perusahaan maka semakin tinggi pengungkapannya.

\section{SIMPULAN}

1. Pengujian koefisien regresi secara serentak (uji F) menghasilkan variabel independen Current Ratio, Debt to Equity Ratio, Total Assets Turnover, Return On Investment, dan Total Debt to Total Assets Ratio berpengaruh terhadap variabel dependen yaitu harga saham. Hal ini ditunjukan dengan nilai sig $\mathrm{F}>0,05$ yang berarti $\mathrm{H}_{0}$ diterima.

2. Pengujian masing- masing variabel independen terhadap harga saham menggunakan uji t. Dari hasil regresi berganda, menghasilkan variabel Current Ratio, Debt to Equity 
Ratio, dan Return on Investment berpengaruh terhadap harga saham terhadap perusahaan pertambangan yang terdapat di bursa efek indonesia. Sedangkan variabel Total Asset Turnover dan variabel Total Debt to Total Asset Turnover tidak berpengaruh terhadap harga saham pada perusahaan pertambangan di Bursa Efek Indonesia.

3. Untuk penelitian selanjutnya data yang dibutuhkan dalam penelitian agar lebih lengkap dan melakukan survei terlebih dahulu sebelum melakukan penelitian. Rasio keuangan yang digunakan adalah rasio keuangan yang bersangkutan dan Rasio keuangan yang dimasukan mencakup seluruh rasio keuangan suatu perusahaan.

4. Terbatasnya data yang didapat dalam penelitian ini sehingga menghambat dan mengurangi jangka waktu dalam penelitian ini dan terbatasnya jumlah sampel dikarenakan pendeknya jangka waktu penyelesaian sebaiknya waktu yang dipergunakan untuk penelitian diperluas.

\section{DAFTAR PUSTAKA}

Agnes, Sawir. 2009. Analisis Kinerja Keuangan dan Perencanaan Keuangan. PT. Gramedia Pustaka Utama. Jakarta

Fahmi, Irham. 2011. Analisis Laporan Keuangan. Lampulo: ALFABETA.

Harahap, Sofyan Syafri. 2009. Analisis Kritis atas Laporan Keuangan, PT Raja Grafindo Persada, Jakarta.

Husnan, Suad. 2007. Manajemen Keuangan Teori dan Penerapan (Keputusan Jangka Panjang). Edisi 4. Yogyakarta:BPFE

Ikatan Akuntansi Indonesia (IAI). 2015. Pernyataan Standar Akuntansi Keuangan (PSAK) No.1: Penyajian Laporan Keuangan. Jakarta: IAI

Kurniawan, Ary. 2008. Pengaruh Kinerja Keuangan Terhadap Return Saham Pada Perusahaan yang terdaftar di Bursa Efek Indonesia. Jurnal Informasi, Perpajakan, Akuntansi dan Keuangan.

Megarini , Laksmi Savitri. 2003. Analisis Pengaruh Kinerja Keuangan Terhadap Perubahan Harga Saham Pada Perusahaan Yang Terdaftar Di Bursa Efek Jakarta. Universitas Sebelas Maret. Surakarta

Martono dan Harjito, Agus. 2010. Manajemen Keuangan. Edisi 3. Yogyakarta.

Munawir S. 2002. Analisis Informasi Keuangan. Penerbit Liberty. Yogyakarta.

Sucipto. 2003. Penilaian Kinerja Keuangan. Jurnal Akuntansi. Universitas Sumatra Utara. Medan.

Sunariyah. 2006. Pengantar Pengetahuan Pasar Modal. Edisi Ketiga. YKPN. Yogyakarta

Widiatmodjo, Sawidji. 2005. Cara Sehat Investasi di Pasar Modal. Media Komputindo. Jakarta 